\title{
Frequency of Vitamin D Deficiency in Children: A Single- Center Cross-Sectional Study in Istanbul
}

\section{Çocuklarda D Vitamini Eksikliğinin Sıklığı: İstanbul'da Tek Merkezli Kesitsel Bir Çalışma}

\author{
@Muhammet Ali Varkal, @Mustafa Özçetin, Ayşe Kılıç \\ Istanbul University School of Medicine Department of Pediatrics, Division of General Pediatrics, Istanbul, Turkey
}

\begin{abstract}
Aim: Vitamin D deficiency is highly prevalent among children worldwide. This study aims to assess the frequency of vitamin D deficiency in children and how it varies according to gender, age, and season in Istanbul.
\end{abstract}

Material and Method: The study included 3096 children aged 0-18 admitted to the pediatric outpatient clinic in Istanbul. The serum 25 hydroxyvitamin D concentration was analyzed by the HighPerformance Liquid Chromatography method using HPLC systems analyzers, and the results were categorized into four groups: deficiency $(<20 \mathrm{ng} / \mathrm{mL})$, insufficiency $(20-30 \mathrm{ng} / \mathrm{mL})$, sufficiency (30-100 ng/mL), and toxicity (>100 ng/mL). Descriptive methods, Chi-square, Independent Samples T-Test, ANOVA, and correlation test were used in the statistical analysis of the data.

Results: Of children, $52 \%$ were girls and $48 \%$ boys. The mean serum 25 hydroxyvitamin D concentration was $21.8 \pm 15.8 \mathrm{ng} / \mathrm{mL}$, and the frequency of vitamin $D$ deficiency was $53.1 \%$. There was a different distribution of vitamin D status between age groups. Vitamin D deficiency was more common in older children. The frequency of vitamin $D$ deficiency was significantly higher in girls than boys (57.6\% versus $48.3 \%$ ). The mean serum 25 hydroxyvitamin D concentration was significantly lower in winter and spring. A moderate negative correlation was found between age and serum 25 hydroxyvitamin D concentration (correlation coefficient:-0.36).

Conclusion: This study showed that female sex, older children, and the winter/spring seasons were significantly associated with a higher frequency of vitamin D deficiency and a lower mean serum 25 hydroxyvitamin D concentration.

Keywords: Vitamin D deficiency, children, outpatient clinic, frequency
Öz

Amaç: D vitamini eksikliği dünya çapında çocuklar arasında oldukça yaygındır. Bu çalışmada, İstanbul Tıp Fakültesi çocuk polikliniğine başvuranlarda D vitamini eksikliği sıklı̆̆ının cinsiyet, yaş ve mevsime göre nasıl değiştiğinin değerlendirilmesi amaçlanmıştır.

Gereç ve Yöntem: Araştırmaya İstanbul'da çocuk polikliniğine başvuran 0-18 yaş arası kronik hastalığı olmayan 3096 çocuk dahil edildi. HPLC sistem analizörleri kullanılarak Yüksek Performanslı SIVı Kromatografi yöntemiyle analiz edilen Serum 25 hidroksivitamin D konsantrasyonu dört grupta değerlendirildi; eksiklik (<20 ng/mL), yetersizlik (20-30 ng/mL), yeterlilik (30-100 ng/mL) ve toksisite (>100 $\mathrm{ng} / \mathrm{mL}$ ). Verilerin istatistiksel analizinde tanımlayıcı yöntemler, Ki-kare, Bağımsız Örneklem T-Testi, ANOVA ve korelasyon testi kullanıldı.

Bulgular: Çocukların \%52'si kız, \%48'i erkekti. Ortalama serum 25 hidroksivitamin D konsantrasyonu $21,8 \pm 15,8 \mathrm{ng} / \mathrm{mL}$ ve $D$ vitamini eksikliği sıkığı \%53,1 idi. Yaş grupları arasında D vitamini eksikliği anlamlı olarak farklıydı. Yaş ilerledikçe eksikliğin arttığı görüldü. D vitamini eksikliğinin sıklığı kızlarda erkeklere göre anlamlı olarak daha yüksekti (\%57,6'ya \%48,3). Ortalama serum 25 hidroksivitamin D konsantrasyonu kış ve ilkbaharda önemli ölçüde daha düşüktü. Yaş ile serum 25 hidroksivitamin D konsantrasyonu arasında orta derecede negatif korelasyon bulundu (korelasyon katsayısı: -0,36).

Sonuç: Bu çalışma, kadın cinsiyetin, yaşı büyük çocukların ve kış/ ilkbahar mevsimlerinin, daha yüksek D vitamini eksikliği sıklığı ve daha düşük bir ortalama serum 25 hidroksivitamin D konsantrasyonu ile önemli ölçüde ilişkili olduğunu gösterdi.

Anahtar Kelimeler: D vitamini eksikliği, çocuk, poliklinik, sıklık

Corresponding (illetişim): Muhammet Ali Varkal, M.D., Istanbul University School of Medicine Department of Pediatrics, Division of General Pediatrics, Istanbul, Turkey

E-mail (E-posta): drmavarkal@gmail.com

Received (Geliş Tarihi): 18.08.2021 Accepted (Kabul Tarihi): 08.09.2021 


\section{INTRODUCTION}

Vitamin $D$ is a steroid hormone that plays a vital role in human physiology and is mainly synthesized in the skin by sunlight. Humans also obtain vitamin D from foods and supplements. [1] Vitamin D is necessary for calcium homeostasis, bone mineralization, and providing the intestinal absorption of calcium and phosphorus. ${ }^{[1]}$ Vitamin $D$ also has extramusculoskeletal roles. Evidence shows that vitamin D deficiency is related to autoimmune disorders, cardiovascular disease, diabetes, and immune deficiency, in addition to rickets and other musculoskeletal disorders. ${ }^{[2-5]}$

Vitamin D deficiency is highly prevalent among children worldwide. ${ }^{[2]}$ Similarly, vitamin D deficiency was commonly reported in studies conducted in different regions of Turkey. ${ }^{[6-10]}$ In most studies, vitamin D deficiency prevalence estimates vary due to deficiency definitions, assessed areas, and considered risk factors. Primary causes of vitamin D deficiency are inadequate vitamin $D$ intake by nutrition and insufficient sunlight exposure. ${ }^{[4]}$ However, vitamin D metabolism is affected by many factors. Wearing sun-protective clothes, living at a northern latitude, winter season, dark skin or race, female gender, and sunscreen creams reduce vitamin D synthesis in the skin. ${ }^{[4]}$ In addition, obesity, fat malabsorption syndromes, hyperparathyroidism, some medications such as anticonvulsants and anti-HIV drugs are associated with vitamin D deficiency. ${ }^{[2]}$

The present study objective was to investigate the rate of vitamin D deficiency and investigate the effects of age, gender, and season in children with similar living conditions by using data available on vitamin D in a large sample in Istanbul.

\section{MATERIAL AND METHOD}

Study design: The study was designed as a single-center and cross-sectional observational study. The study period is between February 2020 and February 2021.

Participant and data collection: A total of 3096 children aged 0 to 18 years admitted to the pediatric outpatient clinic in Istanbul Medical Faculty were enrolled. Subjects who had any chronic diseases such as skeletal diseases, genetic syndromes, or malabsorptive disorders were excluded from the study.
Data were obtained from the hospital database. Demographic features and serum vitamin D levels of participants were enrolled. Age was divided into four groups: infantile period ( 0 days -1 year), toddler period and preschool age (2-7 years), puberty period (8-13 years), and adolescence (14-18 years).

Laboratory assessment: The serum 25 hydroxyvitamin D concentration was analyzed by the High-Performance Liquid Chromatography method using HPLC systems analyzers. Vitamin D status was categorized into four groups: deficiency (<20 ng/mL), insufficiency (20-30 ng/mL), sufficiency (30-100 $\mathrm{ng} / \mathrm{mL})$, and toxicity $(>100 \mathrm{ng} / \mathrm{mL})(2)$.

Statistical analyses: Data were evaluated using IBM SPSS 21 for Windows. Equality of variances was checked with Levene's Test for Equality of Variances, and normality of distribution was examined with the Kolmogorov-Smirnov test. Descriptive statistical analyses were used to obtain the means and standard deviations of continuous variables. Independent Sample T-Test and One-way ANOVA were used to compare variables between the separate groups. In addition, the Chisquare test was used to compare frequencies. P values $<0.05$ were accepted as significant.

Ethical approval: The study was carried out with the permission of İstanbul University Faculty of Medicine Department of Child Health and Diseases Ethics Committee (Date: 10.09.2021, Decision No: 2021/1482-16).

\section{RESULTS}

Of a total of 3096 children, $52 \%$ were girls and $48 \%$ boys. The mean serum $25(\mathrm{OH}) \mathrm{D}$ concentration was $21.8 \pm 15.8 \mathrm{ng} / \mathrm{mL}$, and the frequency of vitamin D deficiency was $53.1 \%$. There was a different distribution of vitamin $D$ status between age groups. The frequency of vitamin D deficiency in the infantile age group was found at $9 \%$. However, the frequency in the adolescent group was $70.1 \%$. Demographic properties and serum vitamin $D$ status according to sex and age group are summarized in Table 1.

A significant difference in serum $25(\mathrm{OH}) \mathrm{D}$ concentration was found between girls $(20.6 \pm 15.5 \mathrm{ng} / \mathrm{mL}$ and boys $(23.1 \pm 16.0$ $\mathrm{ng} / \mathrm{mL}$ ). There was also a significant difference between girls and boys in the frequency of vitamin D deficiency $(57.6 \%$ versus 48.3\%) (Table 2).

\begin{tabular}{|c|c|c|c|c|c|c|c|}
\hline Girl & 1599.52 & $8.8 \pm 5.4$ & $20.6 \pm 15.5$ & 57.6 & 23.1 & 18.9 & 0.3 \\
\hline \multicolumn{8}{|c|}{ Age group } \\
\hline $0-1$ y & 199.6 & $0.6 \pm 0.2$ & $44.0 \pm 30.3$ & 9.0 & 14.1 & 75.4 & 1.5 \\
\hline $2-7 y$ & 1160.37 & $3.7 \pm 1.8$ & $24.5 \pm 13.2$ & 41.3 & 28.6 & 29.9 & 0.2 \\
\hline $14-18 y$ & 762.25 & $15.5 \pm 1.5$ & $16.5 \pm 12.8$ & 70.1 & 20.7 & 8.8 & 0.4 \\
\hline Total & 3096 & $8.4 \pm 5.3$ & $21.8 \pm 15.8$ & 53.1 & 24.9 & 21.7 & 0.3 \\
\hline
\end{tabular}

$\mathrm{y}$ : year, Age and serum vitamin D parameters presented as mean \pm standard deviation, Serum vitamin $D$ values $<20 \mathrm{ng} / \mathrm{mL}$ were accepted as a deficiency, $20-30 \mathrm{ng} / \mathrm{mL}$ as insufficiency, $30-100 \mathrm{ng} / \mathrm{mL}$ as sufficiency and $>100 \mathrm{ng} / \mathrm{mL}$ as toxicity. 


\begin{tabular}{|c|c|c|c|c|}
\hline & $\begin{array}{l}\text { All cases } \\
\mathrm{n}=3096\end{array}$ & $\begin{array}{c}\text { Girl } \\
\mathrm{n}=1599\end{array}$ & $\begin{array}{c}\text { Boy } \\
n=1497\end{array}$ & $\mathbf{p}$ \\
\hline Serum vitamin $D$ & $21.8 \pm 15.8$ & $20.6 \pm 15.5$ & $23.1 \pm 16.0$ & $<0.05$ \\
\hline \multicolumn{5}{|c|}{ Vitamin D status, n (\%) } \\
\hline Deficiency & $1644(53.1)$ & $921(57.6)$ & $723(48.3)$ & $<0.05$ \\
\hline Insufficiency & 772 (24.9) & $370(23.1)$ & $404(26.9)$ & $<0.05$ \\
\hline Sufficiency & $671(21.7)$ & $303(18.9)$ & $368(24.6)$ & $<0.05$ \\
\hline Toxicity & $9(0.3)$ & $5(0.3)$ & $4(0.3)$ & $>0.05$ \\
\hline
\end{tabular}

There were also significant differences in mean serum $25(\mathrm{OH}) \mathrm{D}$ levels between seasons. Mean serum 25(OH) D concentration was the lowest in winter and the highest in summer. The mean serum $25(\mathrm{OH})$ D concentration was significantly lower in winter and spring (Table $\mathbf{3}$ ).

\begin{tabular}{|c|c|c|c|c|c|}
\hline & $\begin{array}{l}\text { Allcases } \\
n=3096\end{array}$ & $\begin{array}{l}\text { Winter } \\
\mathbf{n}=1201\end{array}$ & $\begin{array}{l}\text { Spring } \\
n=268\end{array}$ & $\begin{array}{c}\text { Summer } \\
\mathrm{n}=\mathbf{8 4 3}\end{array}$ & $\begin{array}{c}\text { Fall } \\
n=784\end{array}$ \\
\hline $\begin{array}{l}\text { Serum } \\
\text { vitamin D }\end{array}$ & $21.8 \pm 15.8$ & $17.6 \pm 15.4$ & $19.8 \pm 12.7$ & $26.3 \pm 17.1$ & $24.2 \pm 14.0$ \\
\hline \multicolumn{6}{|c|}{ Vitamin D status, n (\%) } \\
\hline Deficiency & $1644(53.1)$ & $842(70.1)$ & $163(60.8)$ & 303 (35.9) & $336(42.9)$ \\
\hline Insufficiency & $772(24.9)$ & $204(17.0)$ & $65(24.3)$ & $266(31.6)$ & $237(30.2)$ \\
\hline Sufficiency & 671 (21.7) & 152 (12.7) & 40 (14.9) & $270(32.0)$ & 209 (26.7) \\
\hline Toxicity & $9(0.3)$ & $3(0.2)$ & $0(0.0)$ & $4(0.5)$ & $2(0.3)$ \\
\hline \multicolumn{6}{|c|}{$\begin{array}{l}\text { Serum vitamin } D \text { parameters presented as mean } \pm \text { standard deviation, Serum vitamin } D \text { values }<20 \\
\mathrm{ng} / \mathrm{mL} \text { were accepted as a deficiency, } 20-30 \mathrm{ng} / \mathrm{mL} \text { as insufficiency, } 30-100 \mathrm{ng} / \mathrm{mL} \text { as sufficiency and } \\
>100 \mathrm{ng} / \mathrm{mL} \text { as toxicity. }\end{array}$} \\
\hline
\end{tabular}

Chi-square test results showed significant differences in the frequency of vitamin D deficiency, insufficiency, and sufficiency in different sex, ages, and seasons. In addition, One-way ANOVA with post hoc analysis showed significant differences in the mean serum $25(\mathrm{OH})$ D concentration in different age groups and seasons. Among children, female sex, older children, and the winter/spring seasons were significantly associated with a higher frequency of vitamin $D$ deficiency and a lower mean serum $25(\mathrm{OH}) \mathrm{D}$ concentration.

A moderate negative correlation was found between age and serum 25(OH) D concentration (correlation coefficient:-0.36).

\section{DISCUSSION}

We conducted a cross-sectional observational study with a large sample to investigate the rate of vitamin D deficiency and insufficiency in the pediatric outpatient clinic and evaluated demographic features and laboratory data of 3096 children aged $0-18$. The results showed that Vitamin D deficiency (53.1\%) and insufficiency (24.9\%) were highly prevalent in children living in Istanbul. In particular, the rate of vitamin $D$ deficiency was significantly higher in girls and adolescents. Besides, vitamin D deficiency was most common in winter.
Vitamin D deficiency is a global problem, varying in frequency in different populations. ${ }^{[1]}$ In recent studies conducted in Turkey, the prevalence of vitamin D deficiency has been reported from $16.5 \%$ to $89.6 \%$ (Table 4). ${ }^{[6-17]}$ Among these studies, the highest rate of vitamin D deficiency was found in the study included pubertal children and adolescents. ${ }^{[11]}$ The lowest deficiency rate was shown in a study conducted on children younger than 10 years old. ${ }^{[15]}$ However, the studies with all pediatric age groups reported that vitamin D deficiency was in the range of $35.1 \%$ to $65.0 \% .^{[7,8,13,14,16,17]}$ In a study with more than ninety thousand participants, Sahin et al. ${ }^{[6]}$ found that vitamin D deficiency was $45-50 \%$ in children younger than 10 and $80-90 \%$ older than 10 . The results of this study were significant due to the high number of participants. In another study conducted by Yetim et al. ${ }^{[10]}$, the rate of vitamin D deficiency in children older than 10 was reported as $56 \%$. Many studies also showed this relationship, as in the present study (Table 5). $\cdot^{[9,13,16,18-20]}$ In contrast, some studies found a lower frequency of vitamin D deficiency in adolescents. ${ }^{[8,21]}$

A cohort study of neonates performed by Kanike et al. ${ }^{[22]}$ reported a high prevalence of vitamin D deficiency (31\%) and insufficiency (49\%) at birth. Similarly, a multicenter study in China conducted by Yang et al. ${ }^{[19]}$ reported that vitamin $D$ deficiency was seen most commonly in neonates. These two studies pointed to maternal vitamin $D$ deficiency as the cause of vitamin D deficiency in infants. Similar studies also showed this relationship. ${ }^{[23-25]}$ However, this study was unable to analyze this due to the small number of neonates.

Some studies found that the frequency of vitamin D deficiency was higher in girls as in the present study. ${ }^{[9,16]}$ However, some studies reported no difference. ${ }^{[18,26]}$ Cultural factors also have an essential role in vitamin D levels. In particular, traditional dress-style limits sun exposure and decreases vitamin D production. Therefore, vitamin D deficiency prevalence was reported higher among girls in Muslim countries. [20,27-29]

Many studies reported that vitamin D levels were at the lowest in spring and winter. ${ }^{[16,19]}$ Sunlight exposure is the main factor in vitamin D synthesis. High latitudes are associated with inadequate levels of vitamin D. However; vitamin D insufficiency is not explained only by season and latitude. Recently, vitamin D insufficiency and deficiency are reported commonly in sunny countries. ${ }^{[30-33]}$

The present study assessed the role of age, sex, and season on vitamin $D$ deficiency. A large sample of participants was the strong aspect of our research. However, there were a few significant limitations to this study. First of all, it was a crosssectional design study and could not reflect the cause-effect relationship. Secondly, some important factors affecting vitamin D concentration, such as body composition and physical activity, skin pigmentation and sun exposure time, vitamin D intake, and socioeconomic status, could not be evaluated. ${ }^{[1]}$ Many studies have established the relationship between obesity and lower serum vitamin D concentrations. [18,27,34-36] Vitamin D deficiency related to obesity is likely due 
to the deposition of vitamin $\mathrm{D}$ in body fat tissues and the decreased bioavailability. ${ }^{[36]}$ It has long been known that ethnicity and darker skin can greatly reduce vitamin D synthesis. ${ }^{[37]}$
Low vitamin D intake and breastfeeding were other important causes of vitamin D deficiency. ${ }^{[1,23]}$ In addition, many study results showed that vitamin $\mathrm{D}$ deficiency was more prevalent among populations with lower socioeconomic status. ${ }^{[18,27,38,39]}$

\begin{tabular}{|c|c|c|c|c|c|}
\hline Year & $\mathbf{n}$ & Age & $\begin{array}{c}\text { Mean Serum } \\
\text { Vitamin } D(\mathrm{ng} / \mathrm{mL})\end{array}$ & Deficiency \% & Insufficiency \% \\
\hline 2015 & 2909 & $0-18 y$ & $28.0 \pm 15.5$ & 35.1 & 61.2 \\
\hline 2016 & 171 & $3-18 y$ & - & 86.6 & - \\
\hline & 775 & $0-10 y$ & & 16.5 & 25.3 \\
\hline 2016 & 335 & - & $32.9 \pm 13.9$ & - & - \\
\hline & 187 & $10-20 y$ & - & 56 & 36 \\
\hline 2017 & 103 & - & $18.7 \pm 8.9$ & - & - \\
\hline & 84 & - & $19.2 \pm 9.3$ & - & - \\
\hline & 2346 & $0-18 y$ & - & 42.3 & 27.3 \\
\hline 2018 & & - & $21.3 \pm 15.0$ & - & - \\
\hline & 90042 & $0-18 y$ & - & - & - \\
\hline & 47928 & & $22.3 \pm 14.0$ & - & - \\
\hline 2018 & 42114 & & $25.3 \pm 13.4$ & - & - \\
\hline & - & & - & $45-50$ & - \\
\hline & - & & - & $80-90$ & - \\
\hline 2018 & 346 & $0-18 y$ & - & 49.1 & 27.5 \\
\hline 2019 & 77 & $6-18 y$ & - & 89.6 & 10.4 \\
\hline 2019 & 103 & $0-14 y$ & $23.9 \pm 13.7$ & 49 & - \\
\hline 2020 & 4153 & $0-17 y$ & $18.1 \pm 11.2$ & 65.0 & 23.1 \\
\hline 2021 & 3096 & $0-18 y$ & $21.8 \pm 15.8$ & 53.1 & 24.9 \\
\hline
\end{tabular}

y: year, Serum vitamin D parameters presented as mean \pm standard deviation, Serum vitamin D values $<20 \mathrm{ng} / \mathrm{mL}$ were accepted as a deficiency and $20-30 \mathrm{ng} / \mathrm{mL}$ as insufficiency. The present study

Table 5. Studies on the prevalence of vitamin D deficiency

\begin{tabular}{|c|c|c|c|c|c|c|}
\hline Study & Year & $\mathbf{n}$ & Age & $\begin{array}{l}\text { Mean/Median Serum } \\
\text { Vitamin D (ng/mL) }\end{array}$ & Deficiency \% & Insufficiency \% \\
\hline Healthy-Weight & & 7728 & & - & 21 & - \\
\hline Obese & & 1897 & & - & 34 & - \\
\hline Severely obese & & 581 & & - & 49 & - \\
\hline Zhang et al. ${ }^{[34]}$ & 2014 & 1488 & $7-11 y$ & $18.4(6.7-33.1)$ & 56.4 & 23.3 \\
\hline Al-Sadat et al. ${ }^{[27]}$ & 2016 & 1361 & $13-15 y$ & - & 92.6 & - \\
\hline \multirow{4}{*}{ Beer et al. ${ }^{[21] *}$} & \multirow{4}{*}{2020} & 2104 & $1-2 y$ & $23.0 \pm 16$ & 42.5 & - \\
\hline & & 6813 & $2-5 y$ & $26.1 \pm 19$ & 27.7 & - \\
\hline & & 16454 & $5-13 y$ & $26.4 \pm 23$ & 21.8 & - \\
\hline & & 6470 & $13-18 y$ & $26.9 \pm 19$ & 20.4 & - \\
\hline Kanike et al. ${ }^{[22] \dagger}$ & 2020 & 1517 & newborn & $19.0(3-223)$ & 31 & 49 \\
\hline
\end{tabular}

y: year, Serum vitamin D parameters presented as mean \pm standard deviation or median (minimum-maximum), Serum vitamin D values $<20 \mathrm{ng} / \mathrm{mL}$ were accepted as a deficiency and $20-30 \mathrm{ng} / \mathrm{mL}$ as insufficiency. * In the study, standard errors were converted to standard deviation, and serum vitamin D values $<20 \mathrm{ng} / \mathrm{mL}$ were shown in the deficiency column. tIn the study, serum vitamin D values $<15 \mathrm{ng} / \mathrm{mL}$ were accepted as a deficiency and $15-30 \mathrm{ng} / \mathrm{mL}$ as insufficiency. ¥The present study 


\section{CONCLUSION}

This study showed that female sex, older children, and the winter/spring seasons were significantly associated with a higher frequency of vitamin D deficiency and a lower mean serum 25 hydroxyvitamin $D$ concentration. The study findings suggest the need for caution in vitamin D supplementation of girls and older children. These children may require additional vitamin D supplementation to prevent vitamin D deficiency.

\section{ETHICAL DECLARATIONS}

Ethics Committee Approval: The study was carried out with the permission of İstanbul University Faculty of Medicine Department of Child Health and Diseases Ethics Committee (Date: 10.09.2021, Decision No: 2021/1482-16).

Informed Consent: Because the study was designed retrospectively, no written informed consent form was obtained from patients.

Referee Evaluation Process: Externally peer-reviewed.

Conflict of Interest Statement: The author(s) declared no potential conflicts of interest with respect to the research, authorship, and/or publication of this article.

Financial Disclosure: The authors declared that this study has received no financial support.

Author Contributions: All of the authors declare that they have all participated in the design, execution, and analysis of the paper, and that they have approved the final version.

\section{REFERENCES}

1. Holick MF. Medical progress: Vitamin D deficiency. N Engl J Med 2007;357(3):266-81.

2. Holick MF, Binkley NC, Bischoff-Ferrari HA, et al. Evaluation, treatment, and prevention of vitamin $D$ deficiency: An endocrine society clinical practice guideline. J Clin Endocrinol Metab 2011;96(7):1911-30.

3. Holick MF. Sunlight and vitamin D for bone health and prevention of autoimmune diseases, cancers, and cardiovascular disease. Am J Clin Nutr 2004;80(6 Suppl):1678-88.

4. Huh SY, Gordon CM. Vitamin D deficiency in children and adolescents: Epidemiology, impact and treatment. Rev Endocr Metab Disord 2008:161-70.

5. Holick MF. Vitamin D. Important for prevention of osteoporosis, cardiovascular heart disease, type 1 diabetes, autoimmune diseases, and some cancers. South Med J 2005;98(10):1024-7.

6. Sahin ON, Serdar M, Serteser M, Unsal I, Ozpinar A. Vitamin D levels and parathyroid hormone variations of children living in a subtropical climate: A data mining study. Ital J Pediatr 2018;44(1):1-7.

7. Coşkun C, Şahin K. Correlation between vitamin D level and platelet indices in children aged 0-18 years. Haseki Tip Bul 2018;56(2):153-7.

8. Türe $E$, Müderrisoğlu $S, A c I R$, Çubukçu M, Erdem MA. Evaluation of Vitamin D Levels in Adolescents and Children According to Age, Sex and Seasonal Charesteristics. Ankara Med J 2020;20(2):380-6.

9. Demiral M, Sırmagül B, Kirel B. Endokrin polikliniğine başvuran çocuklarda d vitamini düzeyleri. Guncel Pediatr 2016;14(2):60-6.

10. Yetim A, Tıkız C, Baş F. Prevelance of vitamin D and B12 deficiency in adolescence. Çocuk Derg 2017;17(1):24-9.

11. Atasoy V, Ateş Altunbaş E, Set T. Evaluation of Vitamin D levels among overweight and obese children. Türkiye Aile Hekim Derg 2019;23(3):102-
9.

12. Naiboğlu E, Naiboğlu S, Turan E, Hasbal Akkuş C, Hatipoğlu S. Investigation of Vitamin B12 and Vitamin D Deficiency in Patients with Lower Respiratory Tract Infection in Child Clinic. Bakirkoy Tip Derg / Med J Bakirkoy 2019;15(4):339-44.

13. Doğan N, Colak AA, Güden N, Üstüner F. Vitamin D deficiency in children in Aegean Region in Turkey Cumhur Med J 2015;37(1):17-22.

14. Ozhan B, Evrengul H, Yilmaz Agladioglu S, Umit Yasar S, Demir S. Vitamin D Status of Children in a University Hospital in West Turkey. Hong Kong Med J 2016;21:251-6.

15. Bucak IH, Almis H. The Retrospective Analysis of Vitamin D Levels of Pediatric Patients in a Small City Center in Turkey. Sak Med J 2016;6(3):136-40.

16. Topal I, Mertoglu C, Arslan YK et al. Erzincan Bölgesindeki Çocukların D Vitamini Seviyelerinin Yaş, Cinsiyet ve Mevsimlere Göre Değerlendirilmesi. Firat Med J 2018;23(4):168-72.

17. Acik S, Yakinci MC. Vitamin D Levels of Pediatric Intensive Care Patients. Konuralp Tıp Derg 2018;10(3):326-32.

18. Moore CE, Liu Y. Low serum 25-hydroxyvitamin D concentrations are associated with total adiposity of children in the United States: National Health and Examination Survey 2005 to 2006. Nutr Res 2016;36(1):72-9.

19. Yang C, Mao M, Ping L, Yu D. Prevalence of vitamin D deficiency and insufficiency among 460,537 children in 825 hospitals from 18 provinces in mainland China. Medicine (Baltimore). 2020;99(44).

20. Isa H, Almaliki M, Alsabea A, Mohamed A. Vitamin D deficiency in healthy children in Bahrain: Do gender and age matter? East Mediterr Heal J 2020;26(3):260-7.

21. Beer RJ, Herrán OF, Villamor E. Prevalence and correlates of vitamin D deficiency in a tropical setting: results from a nationally representative survey. Am J Clin Nutr 2020;112(4):1088-98.

22. Kanike N, Hospattankar KG, Sharma A, Worley S, Groh-Wargo S. Prevalence of Vitamin D Deficiency in a Large Newborn Cohort from Northern United States and Effect of Intrauterine Drug Exposure. Nutrients 2020;12(7):1-9.

23. Lee JM, Smith JR, Philipp BL et al. Vitamin D deficiency in a healthy group of mothers and newborn infants. Clin Pediatr (Phila) 2007;46(1):42-4.

24. Merewood A, Mehta SD, Grossman X et al. Widespread vitamin D deficiency in urban Massachusetts newborns and their mothers. Pediatrics 2010;125(4):640-7.

25. Halicioglu O, Aksit S, Koc F et al. Vitamin D deficiency in pregnant women and their neonates in spring time in western Turkey. Paediatr Perinat Epidemiol 2012;26(1):53-60.

26. Chen Z, Lv X, Hu W et al. Vitamin D Status and Its Influence on the Health of Preschool Children in Hangzhou. Front Public Heal 2021;9.

27. Al-Sadat N, Majid HA, Sim PY et al. Vitamin D deficiency in Malaysian adolescents aged 13 years: findings from the Malaysian Health and Adolescents Longitudinal Research Team study (MyHeARTs). BMJ Open 2016;6(8).

28. Khor GL, Chee WSS, Shariff ZM et al. High prevalence of vitamin D insufficiency and its association with BMI-for-age among primary school children in Kuala Lumpur, Malaysia. BMC Public Health 2011;11(95):1-8.

29. Shaikh AMA, Abaalkhail B, Soliman A et al. Prevalence of vitamin d deficiency and calcium homeostasis in saudi children. JCRPE J Clin Res Pediatr Endocrinol 2016;8(4):461-7.

30. Levis S, Gomez A, Jimenez C et al. Vitamin D deficiency and seasonal variation in an adult south Florida population. J Clin Endocrinol Metab 2005;90(3):1557-62.

31. Gannagé-Yared MH, Chemali R, Yaacoub N, Halaby G. Hypovitaminosis D in a sunny country: Relation to lifestyle and bone markers. J Bone Miner Res 2000;15(9):1856-62.

32. van der Mei IAF, Ponsonby AL, Engelsen $\mathrm{O}$ et al. The high prevalence of vitamin D insufficiency across Australian populations is only partly explained by season and latitude. Environ. Health Perspect 2007;115(8):1132-9.

33. Mishal AA. Effects of different dress styles on vitamin D levels in healthy young Jordanian women. Osteoporos Int 2001;12(11):931-5. 
34. Zhang $\mathrm{H}$ qi, Teng $\mathrm{J}$ hua, $\mathrm{Li} \mathrm{Y}$ et al. Vitamin $\mathrm{D}$ status and its association with adiposity and oxidative stress in schoolchildren. Nutrition 2014;30(9):1040-4.

35. Turer $C B$, Lin $H$, Flores $G$. Prevalence of vitamin D deficiency among overweight and obese us children. Pediatrics 2013;131(1):152-61.

36. Wortsman J, Matsuoka LY, Chen TC, Lu Z, Holick MF. Decreased bioavailability of vitamin D in obesity. Am J Clin Nutr 2000;72(3):690-3.

37. Clemens TL, Henderson SL, Adams JS, Holick MF. Increased skin pigment reduces the capacity of skin to synthesise vitamin D3. Lancet 1982;319(8263):74-6.

38. Weishaar T, Vergili JM. Vitamin D Status Is a Biological Determinant of Health Disparities. J Acad Nutr Diet 2013;113(5):643-51.

39. Puri S, Marwaha RK, Agarwal N et al. Vitamin D status of apparently healthy schoolgirls from two different socioeconomic strata in Delhi: Relation to nutrition and lifestyle. Br J Nutr 2008;99(4):876-82. 